Reprod. Nutr. Dévelop., 1981, 21 (6B), 1137-1142.

\title{
Participation of glucocorticoids in the regulation of plasma LH levels in the male domestic duck (Anas platyrhynchos L.)
}

\author{
by P. DEVICHE, J.-CI. HENDRICK*
}

Laboratory of Biochemistry, University of Liège,

place Delcour 17, B-4020 Liège, Belgium.

* Laboratory of Radioimmunology,

University of Liège, Liège. Belgium.

Summary. Adult male domestic ducks were treated in autumn for 14 consecutive days with either (i) long-acting ACTH (20 IU/day), (ii) corticosterone $(25 \mathrm{mg} / \mathrm{day}$ ), (iii) dexamethasone $(0.25 \mathrm{mg} /$ day) or (iv) a control solution. Blood samples were obtained from all birds after 1, 3, 7 and 14 injections of hormones; on each of these occasions, a sample was obtained 3 times during the day. The 3 hormonal treatments induced a marked and transient (observed on the 3rd and 7th, but not on the 1st and 14th days of injection) elevation of the LH plasma levels. This increase was not associated with any alteration of the testosterone plasma levels. The results are discussed in view of our knowledge of the influence of adrenal hormones on the pituitary-gonadal axis.

\section{Introduction.}

In mammals, very complex interactions are known to link the pituitary-adrenal and -gonadal axes (see e.g. Andrews, 1977). This degree of complexity has been observed in birds too. Several papers have reported an antigonadotrophic action of corticosterone in male birds. The implantation of corticosterone into the basal hypothalamus of photostimulated sparrows decreases plasma luteinizing hormone (LH) levels and blocks photo-induced testis growth (Wilson and Follett, 1975). Also peripheral administration of high doses of corticosterone to ducklings depresses the LH levels as well as the testis weight (Deviche et al., 1979).

The antigonadotrophic action of corticosterone does not appear, however, to be a general one. For example, in castrated ducks, the transient increase of corticosterone levels, which follows ACTH treatment, is not associated with any alteration of the castration-induced rise of LH or FSH levels (Deviche ef al., 1980). Moreover, ACTHinjected flycatchers do not show any deficit in testicular function, although the experimental treatment presumably stimulates the secretion of corticosteroids (Silverin, 1979) in these birds.

In order to obtain new information on this subject, we carried out an experiment evaluating the short and longer-term repercussions of a treatment with either ACTH, 
dexamethasone (a powerful synthetic corticosteroid) or corticosterone on the LH levels of intact adult male ducks. The present data show that in some circumstances, injections of these hormones can induce a marked transient increase in the circulating levels of the gonadotrophin.

\section{Materials and methods.}

A. Birds. - For the present experiment, we used 20 intact adult male domestic ducks of the Roven breed. All birds were raised together and none of them had been submitted to any hormonal treatment before this study.

The animals were about $31 / 2$ months old at the beginning of the work, which was carried out between September 25 th and October 15 th.

B. Injections. - Before starting the treatments, the ducks were randomly divided into four groups of five males each. Each group was then injected for 14 consecutive days as follows : (i) corticosterone group (=CORT) : $25 \mathrm{mg}$ of corticosterone dissolved in $0.5 \mathrm{ml}$ of propylene glycol ; (ii) dexamethasone group (=DXM) : $0.25 \mathrm{mg}$ of dexamethasone dissolved in $0.5 \mathrm{ml}$ of propylene glycol ; (iii) ACTH group (=ACTH) : $20 \mathrm{IU}$ of long-acting ACTH in $0.5 \mathrm{ml}$ of gelatin solution; (iv) control group (=CONT) : $0.5 \mathrm{ml}$ of propylene glycol. These values correspond to individual daily doses. All hormones were administered into the pectoral muscles in random order between $8: 30$ a.m. and 9:00 a.m.

C. Blood samplings and hormones assays. - Blood samples were collected into heparinized syringes from the wing vein of each male after 1, 3, 7 and 14 injections of hormones. On each of these occasions, a sample was obtained three times during the day, that is in the morning ( $1 \mathrm{~h} 15 \mathrm{~min}$ after injection), at midday ( $5 \mathrm{~h} 15$ min after injection) and in the evening ( $9 \mathrm{~h}$ after injection). All samples were centrifuged for $15 \mathrm{~min}$ at $500 \times \mathrm{g}$; the supernatant plasmas were kept at $-20^{\circ} \mathrm{C}$ until assay.

$\mathrm{LH}$ levels were measured according to the radioimmunoassay method of Follett et al. (1972) with an anti-avian LH serum and purified chicken $\mathrm{LH}(=\mathrm{CHLH})$ as the standard. All assays were run in a single series and in duplicate on $2 \times 100 \mu \mathrm{l}$ of plasma.

Testosterone $(=T)$ levels were measured only in the samples collected after 3 and 7 injections, according to a previously described method (Balthazart, 1976).

Before any computation, all data were transformed into $\log (X+1)$ to minimize the variance ratios between the groups (Dagnelie, 1975).

Results obtained for the hormone-treated groups of birds have been compared to the corresponding results for the control (CONT) group by Student's t-test for independent samples.

\section{Results.}

Results obtained for $\mathrm{LH}$ are presented on figure 1.

The first injection of corticosterone, dexamethasone or ACTH did not alter the $\mathrm{LH}$ levels at any time of the day. After 3 injections, the LH levels were higher in the 3 hor- 

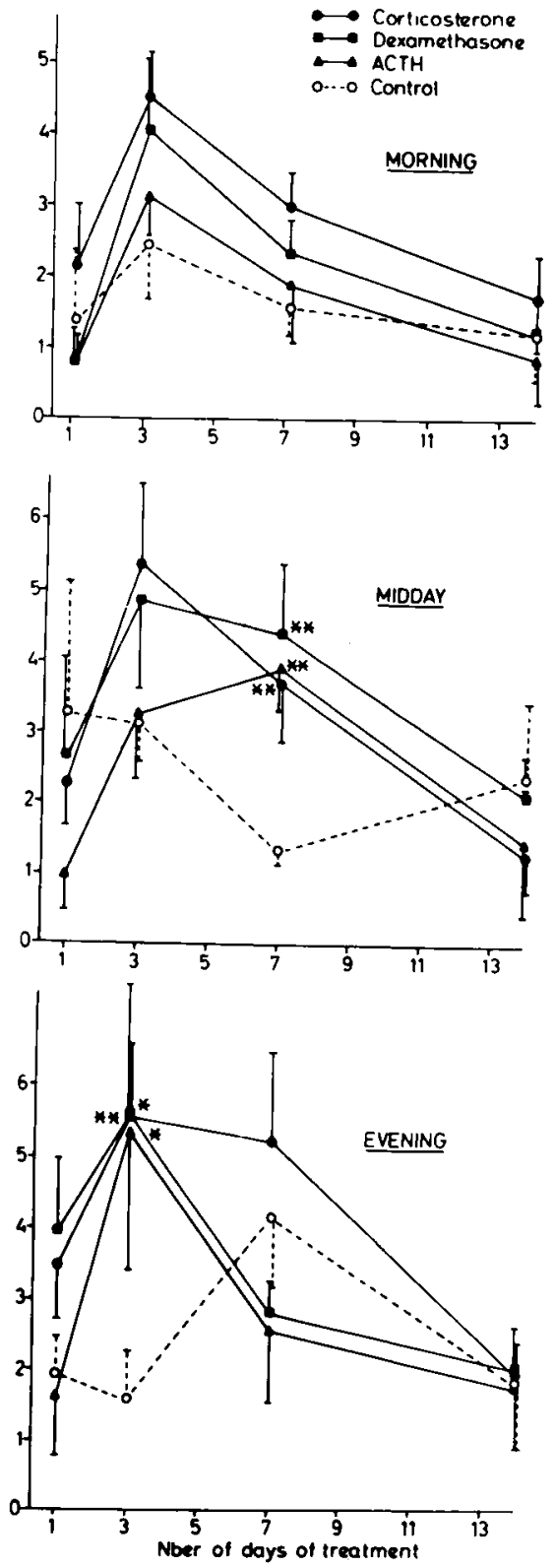

FIG. 1. - Plasma levels of $\mathrm{LH}(\bar{X} \pm$ S. E.; ng CHLH/ml) measured in adult male ducks treated with corficosterone, dexamethasone, ACTH or a control solution. Hormone levels have been evaluated in the four groups of birds after 1, 3,7 and 14 injections, each time at three moments of the day (morning, midday and evening). The results obtained for the 3 experimental groups have been compared to the corresponding data for the control group by the $t$-test for independent samples. Only two-tailed significant probabilities $(p \leqslant 0.05)$ are indicated : ${ }^{*}=0.02<p<0.05 ;{ }^{* *}=0.01<p<0.02$. 
mone-treated groups of males than in the CONT group. These differences were observed in the evening, but not in the morning or at midday. A similar result was obtained on the 7th day of treatment. In that case, however, the differences between the hormone-injected males and the CONT males appeared at midday rather than in the evening. Finally, after the 14th injection, as after the first one, no experimental group differed markedly from the CONT group. The treatment-induced increase of LH levels was therefore only transient. This increase was not associated with any alteration of the T levels. Indeed, after 3 as well as after 7 injections, the steroid titers measured in the experimental males did not differ significantly ( $p$. always $>0.05$ ) from those measured in the CONT males at any time of the day.

\section{Discussion.}

In the tree sparrow, hypothalamic implantation of corticosterone depresses LH levels (Wilson and Follett, 1975). Similarly, peripheral injections of ACTH or corticosterone in adult male ducks decrease the circulating levels of the gonadotrophin (Deviche, 1980). These results make it clear that in some circumstances, corticosterone treatment has an antigonadotrophic action in male birds.

In the present work, however, the administration of corticosterone, ACTH or dexamethasone temporarily increased the LH levels. This difference with previous reports is not attributable solely to the daily quantities of hormones administered to the birds, to the duration of the experimental treatments, nor to the lapse of time separating the hormone injections from the collection of the blood samples. The values of these parameters were indeed within the range of those used in the course of previous studies (Deviche, 1980).

It is also worth pointing out that in the present study, the circulating levels of testosterone were not altered by any treatment. For this reason, increased $\mathrm{LH}$ levels are unlikely to have resulted from decreased festosterone levels. This hormone is known to exert a negative feedback action on the secretion of $\mathrm{LH}$ as well as of FSH (Deviche et al., 1980).

It must be stressed, however, that the present work was carried out in the autumn, while the experiments in which corticosterone (or ACTH) treatment depressed LH levels were conducted in the springtime (Deviche, 1980). This suggests that an experimental elevation of corticosteroid titers in the male duck affects $\mathrm{LH}$ secretion differently depending on the season when the elevation is induced.

The mechanisms involved in the action of corticosteroids on gonadotrophin secretion, however, are speculative at the present time. These mechanisms might be :

a) a direct effect of corticosteroid on the hypothalamus and/or on the pituitary gland. Recent work performed on the rat lends some support to this hypothesis (Fujihara and Shiino, 1980) ;

b) an indirect corticosteroid effect. It has been demonstrated in the male ring dove in vivo that corticosterone injection inhibits the hypothalamic accumulation of a tritiated testosterone metabolite having the chromatographic mobility of dihydrotestosterone (Stern, 1972). This suggests that corticosteroids can alter the metabolism of androgens 
within the brain. Such alteration could play some role in regulating pituitary gonadotrophin secretion.

The seasonally variable action of corticosteroids on LH levels in the duck cannot be explained in a definite way at the present time. In this species, marked fluctuations of the pituitary-gonadal secretions occur during the course of the year (Balthazart and Hendrick, 1976 ; Jallageas ef al., 1978). On the other hand, the in vitro brain metabolism of testosterone changes according to the reproductive condition of the birds (quail : Balthazart et al., 1979).

Therefore, it is quite possible that, depending on the period of the year when corticosteroids are administered, the overall effects of these hormones on the brain metabolism of androgens, and thus possibly on gonadotrophin secretion, vary in a complex fashion. This hypothesis is now under investigation.

Workshop on «Avian male reproduction » Nouzilly, France, June 1980.

Acknowledgments. - We are indebted to Professor Schoffeniels for his continued interest in our work. This study was partly supported by grant nber 2.4544 .76 from the Fonds de la Recherche Fondamentale et Collective to Professor Schoffeniels. P. Deviche is Aspirant du Fonds National de la Recherche Scientifique. Our thanks are due to Professor B. K. Follett for his gift of antiserum to avian $\mathrm{LH}$ and of purified chicken $\mathrm{LH}$. We are much indebted to Dr Stephenson, Armour (Eastbourne, England) for his gift of ACTH.

Résumé. Des canards domestiques adultes ont reçu en automne et ce pendant 14 jours consécutifs, une injection journalière d'ACTH-retard $(20 \mathrm{UI} /$ jour $)$, de corticostérone (25 mg/jour), de dexaméthasone $(0,25 \mathrm{mg} /$ jour $)$ ou de solution contrôle. Des échantillons de sang ont été prélevés chez ces oiseaux après $1,3,7$, ef 14 injections, chaque fois à 3 moments de la journée. Les trois traitements hormonaux ont induit une augmentation marquée ef transitoire (notée aux jours 3 ef 7 , mais non aux jours 1 et 14 d'injection) des taux plasmatiques de la LH. Cette augmentation n'a pas été accompagnée d'altérations des taux plasmatiques de la testostérone. Les résultats sont discutés dans le contexte de nos connaissances de l'influence des glandes surrénales sur l'axe hypophyso-gonadal.

\section{References}

ANDREWS R. V., 1977. Influence of the adrenal gland on gonadal function. In THOMAS J. A., and SINGHAL R. L., Regulatory mechanisms affecting gonadal hormone action, vol. 3 : Advances in sex hormone research. Univ. Park Press, Baltimore.

BALTHAZART J., 1976. Daily variations of behavioural activities and of plasma testosterone levels in the domestic duck Anas platyrhynchos. J. Zool., 180, 155-173.

BALTHAZART J., HENDRICK J. C., 1976. Annual variation in reproductive behavior, testosterone and plasma FSH levels in the Rouen duck, Anas plafyrhynchos. Gen. comp. Endocr., 28, 171-183.

BALTHAZART J., MASSA R., NEGRI-CESI P., 1979. Photoperiodic control of testosterone metabolism, plasma gonadotrophins, cloacal gland growth and reproductive behavior in the Japanese quail. Gen. comp. Endocr., 39, 222-235.

DAGNELIE P., 1975. Théorie et méthodes statistiques, vol. 2, Presses Agronomiques, Gembloux. 
DEVICHE P., 1980. Interactions gonado-surrénaliennes dans la reproduction chez les oiseaux. Th. Doct., Univ. Liège.

DEVICHE P., HEYNS W., BALTHAZART J., HENDRICK J. C., 1979. Inhibition of LH plasma levels by corticosterone administration in the male duckling (Anas platyrhynchos). IRCS Med. Sci., 7, 622.

DEVICHE P., BALTHAZART J., HEYNS W. and HENDRICK J. C., 1980. Endocrine effects of castration followed by androgen replacement and ACTH injections in the male domestic duck (Anas platyrhynchos L.). Gen. comp. Endocr. 41, 53-61.

FOLLETT B., SCANES C., CUNNINGHAM F., 1972. A radioimmunoassay for avian luteinizing hormone. J. Endocr., 52, 359-378.

FUJIHARA N., SHIINO M., 1980. The participation of corticosterone in luteinizing hormone releasing hormone (LH-RH) action on luteinizing hormone (LH) release from anterior pituitary cells in vitro. Life Sci., 26, 777-781.

JALLAGEAS M., TAMISIER A., ASSENMACHER 1., 1978. A comparative study of the annual cycles in sexual and thyroid function in male Peking ducks (Anas platyrhynchos) and teal (Anas crecca). Gen. comp. Endocr., 36, 201-210.

SILVERIN B., 1979. Activity of the adrenal glands in the pied flycatcher and its relation to testicular regression. Gen. comp. Endocr., 38, 162-171.

STERN J. M., 1972. Androgen accumulation in hypothalamus and anterior pituitary of male ring dove ; influence of steroid hormones. Gen. comp. Endocr., 18, 439-449.

WILSON F. E., FOLLETT B. K., 1975. Corticosterone-induced gonadosuppression in photostimulated tree sparrows. Life Sci., 17, 1451-1456. 